\title{
ANTIBACTERIAL ACTIVITY OF MARINE MICROALGAE AGAINST MULTIDRUG RESISTANT HUMAN PATHOGENS
}

\author{
Lazarus.$S^{1}$ and Valentin Bhimba ${ }^{2}$ \\ ${ }^{1}$ Institute for Marine Science and Technology, \\ Manonmaniam Sundaranar University, Tirunelveli, India \\ ${ }^{2}$ Department of Biotechnology, Sathyabama University, Chennai, India \\ E-mail : 'bvbhimba@yahoo.co.in
}

\begin{abstract}
Marine microalgal extracts were studied for their antibacterial activity against the multidrug resistant human pathogens. Twenty marine microalgae were cultured and extracts were screened against 10 human pathogens. Among them, Isochrysis galbana extract showed highest percentage of antibacterial activity. Among the 5 solvents used for the extraction of antimicrobials, $n$-butanol showed maximum extraction $(41.3 \%)$ of antimicrobials. The percentage inhibition of bacterial pathogens by these microalgae showed the maximum inhibition of Escherichia coli.
\end{abstract}

KEYWORDS : Marine microalgal extracts, Multidrug resistant human pathogens, Antibacterial activity.

\section{INTRODUCTION}

The ocean occupies approximately $70 \%$ of the earth's surface and $80 \%$ of animal species resides in this continuous territory due its immense source of food, mineral and energy. The ocean remains one of the natural resources to be utilized fully by man. Marine algae produce many interesting bioactive molecules both lipid and watersoluble which may turn out to be useful for the development of antimicrobial drugs (Siddhanta and Shanmugam, 1999). Pharmaceutical importance of marine algae is very well known all over the world and extensive efforts were made by research workers from India and abroad to bring out the bioactive substances. Marine planktonic algae have been recognized as potential source of antibacterial substances (Duff et al., 1966 and Manivasaham et al., 1993). Antibacterial activity in connection with phytoplankton was first observed by Sieburth (1960) against some soil bacteria. To explore this, the present study have focused on the potential applications of marine microalgae particularly for the treatment of multi drug resistant human pathogens, which can be used as the alternative source for the commonly used effectless antibiotics.

\section{MATERIALS AND METHODS}

\section{Collection of Marine Microalgae}

Algal inoculum of Isochrysis galban, Nannochloropsis occulata, Dicarteria inornata, Chromulina freibergensis, Pavlova lutheri, Tetraselmis gracilis, Tetraselmis tetrahele, Chlorella salina, Chlorella marina, Chaetoceros calcitrans, Skeletonema costatum, Dunaliella salina, Pavlova salina, Nannochloropsis salina, Nitzchia sp., Nannochloris atomus, Anabena sp., Oscillatoria, Chlorella vulgaris, Navicula sp., Platymonas sp., Tetraselmis chuii, Synechocystis sp., Phaeocystis and
Thalassiosira pseudonona were obtained from Central Marine Fisheries Research Institute (CMFRI) at Tuticorin and Vizhinjam, India.

\section{Maintenance of Stock culture}

About $10 \mathrm{ml}$ of the inoculum in the growing phase was inoculated into the autoclaved seawater containing the Walne's medium (Walne, 1974) enriched with vitamins. The cultures were placed in the front of 2 tube lights (1000 lux). After 8-10 days, when the maximum exponential phase was reached, the light was reduced for further growth. A minimum of 5 cultures were kept for each species as stock culture.

\section{Mass culture of different marine microalgae}

About $20 \mathrm{ml}$ of the fully grown culture from the stock culture was used as inoculum for the mass culture. The mass culture was made in seawater, which was sterilized by autoclaving. Finally the culture flasks were placed in front of tube lights of 1000 lux and the temperature ranged between $28-33^{\circ} \mathrm{C}$.

\section{Algal cell count}

From the time of inoculation, about $1 \mathrm{ml}$ of the samples were taken from each flask once in two days and fixed with formalin in order to kill the cells. After thorough mixing, $0.1 \mathrm{ml}$ of the sample was placed in the Neubauer haemocytometer and the cell densities were counted under microscope and the total density was calculated using the formula

Total number of cells $/ \mathrm{ml}=\frac{\text { No. of cells counted }}{\text { No. of squares counted }} \times$ total no. of squares in $\times 10^{4}$

By following the above procedures, exponential phase of the algal cultures was determined. 


\section{Separation of algal cells}

Algal cells in exponential growth phase were recovered from culture by batch centrifuged at $3000 \mathrm{rpm}$ for 10 minutes. The cells were washed in sterile distilled water for three times and then centrifugation at low speed. The quantities of algal pellets were then weighed. microalgae

Preparation of crude antimicrobials from marine

Each $0.5 \mathrm{~g}$ of algal cells were mixed with different solvents (Acetone, Benzene, n-Butanol, ethyl alcohol, and Water) and crushed in mortar and pestle. The solvent extract was then centrifuged at 10,000 rpm for $15 \mathrm{~min}$. Finally the supernatant was collected and stored for further use.

\section{Antibacterial Assay}

The antibacterial activity of the marine microalgal extracts was tested against 9 pathogenic bacteria viz. E.coli, Klebsiella pneumoniae, Proteus vulgaris, Pseudomonas aeruginosa, Pseudomonas fluorescens, Staphylococcus aureus, Streptococcus pyogenes, Vibrio cholerae, Salmonella typh and Bacillus subtilis. The bacterial cultureswere obtained from the Microbiology Laboratory, Institute for Coastal Area Studies, M. S. University. The inoculum was prepared from $24 \mathrm{hrs}$. old culture in nutrient broth.

\section{Antibiotic test with Commercial Antibiotics}

Mullar Hinton Agar plates were prepared and a swab of test culture was taken aseptically and inoculated on the surface of the agar so as to make a lawn. Commercially available antibiotic discs were placed on the agar plate. Bacteria resistant to antibiotic showed no inhibition and they grew upto the edge of the disc whereas the susceptible ones showed a clear zone around the antibiotic disc after incubation at $37^{\circ} \mathrm{C}$ for $24 \mathrm{hrs}$. Zones of inhibition were measured in $\mathrm{mm}$ and recorded.

\section{Sensitivity test (Baurer, 1966)}

The algal extracts were impregnated separately on an empty sterile filter paper disc (Whatmann No. 1 disc measured $4 \mathrm{~mm}$ ). They were screened for the isolated bacterial pathogens on Muller Hinton Agar plates. The zone of inhibition for the bacterial pathogens were recorded and expressed in $\mathrm{mm}$ diameter. Control discs soaked with the respective solvents were also run simultaneously.

\section{RESULTS AND DISCUSSION}

The micro algae like Isochrysis galban, Nannochloropsis occulata, Dicarteria inornata, Chromulina freibergensis, Pavlova lutheri, Tetraselmis gracilis, Tetraselmis tetrahele, Chlorella salina, Chlorella marina, Chaetoceros calcitrans, Skeletonema costatum, Dunaliella salina, Pavlova salina, Nannochloropsis salina,
Nitzchia sp., Nannochloris atomus, Anabena sp., Oscillatoria, Chlorella vulgaris, Navicula sp., Platymonas sp., Tetraselmis chuii, Synechocystis sp., Phaeocystis and Thalassiosira pseudonona were mass cultured using the Walne's media.

While screening with commercially available antibiotics it was found that the human pathogens were multidrug resistant. The multidrug resistant human pathogens were screened for bioactive compounds extracted from marine microalgae with various solvents. Experiments on the extraction of antimicrobials from the microalgal species indicates that Isochrysis galbana (Fig. 1) has rich bioactive compounds (10.2\%) compared to the other algal species. Experiments of Walter and Mahesh (2000) showed that of the eleven marine diatoms screened against bacterial pathogens, 6 showed high antibacterial activity. The present study reveals that the crude extract obtained by n-butanol gave maximum extraction of antimicrobials (41.3\% Fig. 2). From the present study it was found the percentage inhibition of $E$. coli (15.6\%) was the highest (Fig.3) when compared to other pathogens. This was related to the findings of Padmini et al. (1986) who found that the crude extracts obtained with diethyl ether showed better antimicrobial activity than either acetone, methanol or ethanol. This clearly indicates that the strength of active principle depends on the use of a suitable solvent to extract it. So due to the increase of therapeutic resistance to the usual antibiotics and due to its potential antipathogenic actions, there appears to be a significant role for marine microalgae in the control of multidrug resistant bacterial pathogens.

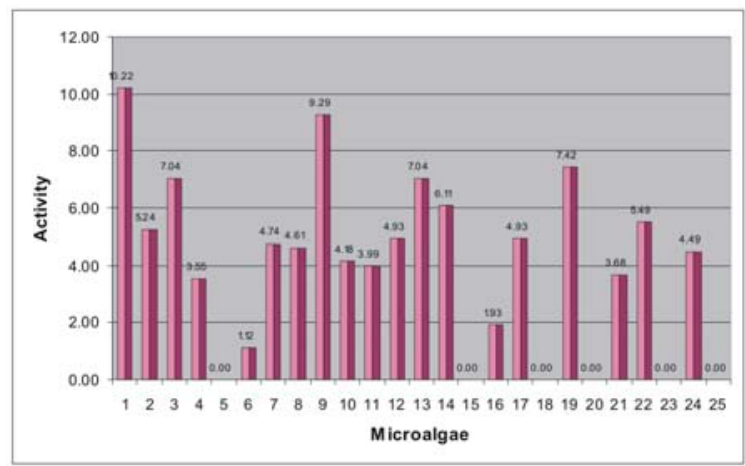

Fig .1 Percentage inhibition of marine microalgae against the pathogens

$\begin{array}{ll}\text { 1) } & \text { Isochrysis galbana } \\ \text { 2) } & \text { Nannochloropsis occulata } \\ \text { 3) } & \text { Dicarteria inornata } \\ \text { 4) } & \text { Chromulina freibergensis } \\ \text { 5) } & \text { Pavlova lutheri } \\ 6) & \text { Tetraselmis gracilis } \\ \text { 7) } & \text { Tetraselmis tetrahele } \\ 8) & \text { Chlorella salina } \\ \text { 9) } & \text { Chlorella marina } \\ \text { 10) } & \text { Chaetoceros calcitrans } \\ \text { 11) } & \text { Skeletonema costatum } \\ \text { 12) } & \text { Dunaliella salina } \\ \text { 13) } & \text { Pavlova salina } \\ \text { 14) } & \text { Nannochloropsis salina }\end{array}$

15)Nitzchia sp.

16)Nannochloris atomus

17)Anabena sp.

18)Oscillatoria

19)Chlorella vulgaris

20)Navicula sp.

21)Platymonas sp

22) Tetraselmis chuii

23)Synechocystis sp.

24)Phaeocystis

25)Thalassiosira pseudonona
Pavlova salina

14) Nannochloropsis salina 


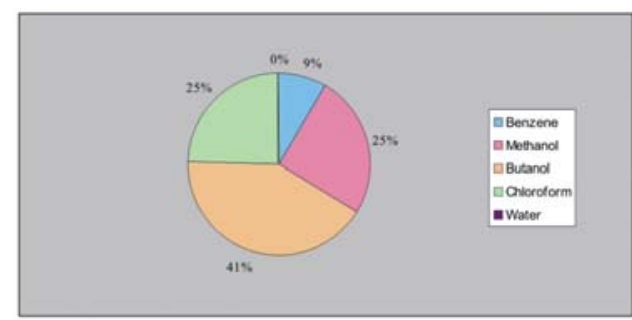

Fig .2 Percentage inhibition of human bacterial pathogens
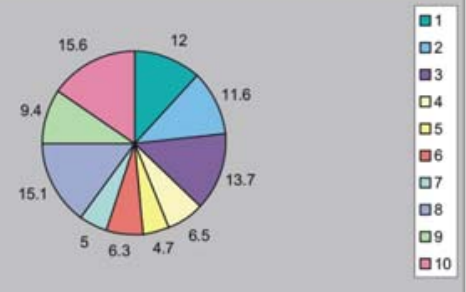

Fig .3 Percentage inhibition of human bacterial pathogens

Klebsiella pneumoniae

Proteus vulgaris

Pseudomonas aeruginosa

Pseudomonas fluorescens

Staphylococcus aureus

Streptococcus pyogenes

Escherichia coli.

Salmonella typhi

Bacillus subtilis

Vibrio cholerae3.

\section{REFERENCES}

[1] Bauer, A.W., Kirby M., Scheris, J.C., and Turuk, M. (1966). Antibiotic susceptibility testing by a standardized single disc method. American Journal of Clinical Pathology, 45: 493-496.

[2] Duff, D.C.B., Bruce D.L., and Antia, N.D. (1996). The antibacterial activity of marine planktonic algae. Canad, Journ. Bact., 12: 877-884.

[3] Manivasaham, S., Mohankumar, A., and Subramaniam, A. (1993). Antibacterial activity of Marine diatom Leptocylindrus minimus Gran. Seaweed Res. Util., 16: 37-40.
[4] Padmini Sreenivasa Rao, P., and Karmarker, S.M. (1986). Biological investigation of Genus Sargassum: antifungal activity of fractions of different species of Sargassum. Phykos., 25: 6-11.

[5] Siddhanta, A.K., and Shanmugam, M. (1999). Metabolites of tropical marine algae of the family Codiaceae Chlorophyta: Chemistry and bioactivity. J. Indian. Chem. Soc., 76: 323-334.

[6] Sieburth, J.M. (1960). Acrylic acid an antibiotic principle in Phaeocystis blooms in Antartic waters. J. Sciences, 132: 676-677.

[7] Walne, P.R. (1974). Culture of bivalve molluscs. Fishing news (Books) Ltd. Survey, U.K., pp. 1-173. Walter, C.S., and Mahesh, R. (2000). Antibacterial andntifungal activities of some marine diatoms in culture, Indian Journal of Marine Sciences, 29: 238-242.

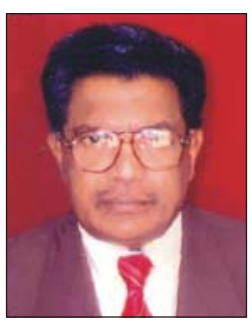

Prof. Lazarus .S is a Scientist of international repute with Ph.D and D.Sc degrees to his credit. He belonged to the Agricultural Research Service of the Indian Council of Agricultural Research and worked as Principal Scientist in the Central Marine Fisheries Research Institute for 26 years. He is one of the members in the Roaster of Experts in the Marine and Coastal Biological Diversity of the United Nations Environmental Programme, Canada and Marine Stewardship Council, United Kingdom .He is the founder Chairman of the Institute for Environmental Research and Social Education, which is an internationally recognized Research Organization for doing underwater marine research using SCUBA in India. He has published more than 150 research papers in national and international research journals and produced a number of Ph.Ds and M.Phils during his research career. 